these things put the method outside the realm of practical medicine; at any rate, outside the walls of a well-equipped institution.

Though he cannot agree with the author, and though, if he had pneumonia, he would rather be treated by some shrewd general practitioner than by the methods advocated, nevertheless, the reviewer will give this book a place of honour on his shelves and read it again from cover to cover and go to it as a valuable book of reference. The work on specific serum-therapy must and will continue, but it is to be hoped that simpler methods and a less drastic technique will be evolved.

\section{HANDBOOK OF DIETS.}

\section{(Second Edition.)}

By Rose M. Simmonds, S.R.N. Dietitian'to the Hammersmith Hospital (Post-Graduate School), London County Council; . Late Dietitian to the London Hospital. With a foreword by LORD DAwSON OF PENN, P.C., G.C.V.O., K.C.B., M.D.(Lond.), Hon. F.R.C.S.(Eng.). William Heinemann, Ltd. 1937. Price 7/6 net.

Miss Simmonds' name is familiar not only to dietitians and to nurses in charge of diets, but to a large number of the medical profession as well, and a second edition of her handbook is welcome.

The book is clearly printed and well set out, and the general arrangement is good.

Starting with the constituents of a balanced diet, we go through all the necessary tables which are required if a suitable diet is to be prescribed quickly, and which are generally so difficult to find together, to the prescribing of diabetic diets.

One gramme of protein per kilogramme seems rather a meagre allowance, although it is the measurement usually taken; a man weighing 11 stone 11 lbs. would only get 75 grammes, but mention is made of the higher quantities required for children.

It seems unnecessary to quote twice in full the "Warning to diabetic patients taking insulin" and the "Care of the hypodermic syringe" as is done on pages 27 and 57 , and one of these might be cut out of further editions.

It is pleasant to see the glucose value of a general diet shown as 100 per cent. of the carbohydrate, 58 per cent. of the protein and 10 per cent. of the fat, as even quite experienced dietitians make mistakes here.

The book is very complete, and includes gastrostomy diets, low calcium diets (though these are not only used for the investigation of osteomalacia and Paget's disease), and low purin diets.

The last chapter is devoted to diets for infants and children in health and disease and some special recipes for them.

This book is the best of its sort that has been published for many a long day, and could only have been written by a dietitian familiar with every phase of her work, not only from the theoretical but from the practical aspect.

It deserves, and should have, its place on the shelf of every doctor in active practice.

\section{AN INTRODUCTION TO BACTERIOLOGICAL CHEMISTRY.}

By C. G. Anderson. E. \& S. Livingstone. Edinburgh. 1938. 10/6.

This small book is the first text-book on the chemical aspects of bacteriology which has appeared in this country. It is, therefore, to be welcomed as an attempt to supply a long felt want.

Those, who are engaged in the teaching of bacteriology to students of chemistry or other science students interested in the aspects of bacteriology which are independent of medicine, have had much difficulty in the past in finding any text-book which is really adequate for these students' requirements. The nearest approach to a suitable book is that produced by Buchanan and Fulmer, but this is much too big a book for any student who is merely taking a course in bacteriology as part of another degree and it contains a great deal of matter which has not got a very direct bearing on bacteriology.

It can safely be said that in its own field the book represents an advance on any text-book already existing. It is split up into three parts. There are five introductory chapters dealing principally with the phenomena in physical chemistry and biochemistry which have been found to be of special application in the study of bacteria, such as hydrogen on concentration, colloids and enzyme action. The 
last is a brief digest of the well-known works of Bayliss and of Haldane on the subject of enzymes. The second section of the book deals with bacterial nutrition, respiration, fermentation, etc. There is a considerable variation in the quality of the chapters-that on nutrition of the autotrophic bacteria gives too much the impression of a catalogue, and the same criticism applies to the chapter on bacterial pigments. The chapter on the heterotrophic bacteria is an interesting and valuable one as also that on bacterial respiration. It is noted in the latter that the author does not attempt to differentiate between the bacteria which readily oxidize the para-phenylene-diamines, such as cholera vibrio, and those unable to do so, such as B. coli. On page 105 it is stated that the metabolism of the streptococci is exactly that of the anærobes. In this, as ir $\_$number of other instances in the book, rather sweeping statements are made which would have appeared more satisfactory if the evidence in support had been given or a direct quotation of an authority supplied, since they are neither generally accepted nor obvious conclusions. The chapters on nitrogenous metabolism and carbohydrate breakdown and on fermentation are particularly good. Chapter XV dealing with industrial fermentations might well be extended so as to include the preparation of silage and the retting of flax.

The third and final section of the book gives a summary of the recent work on immunochemistry which has been well brought up-to-date. Finally, there is an appendix on the isolation and identification of metabolic products. The last is much too brief and might well mislead the uninitiated into failing to appreciate the complexity and delicacy of observations of this kind.

In summing up it may be said that the book is a valuable addition to bacteriological literature but that it would serve its purpose more fully if it were half as long again. Too many of the chapters approach unduly to a catalogue of chemical formulæ and the impression is left that the author would be wiser, in view of the wide field of knowledge covered, to associate himself in future editions with one or more joint authors expert in different parts of this field.

\section{Miscellaneous.}

This Section deals with New Drugs, Preparations, Surgical Instruments, etc. The description of each article is supplied by the Producer. Particulars regarding insertions, which are free of cost, may be obtained from the Business Manager, Fellowship of Medicine and Post-Graduate Journal, 404, Grand Buildings, W.C.2.

We learn that again this year all the Oxford Crew took Glucose-D. G. L. regularly Glaxo during the last month of Laboratories their training. According to the President of the Oxford University Boat Club, Glucose-D. in 1937 " played no small part in the winning of the Boat Race" and, following last year's satisfactory result, the victorious crew again adopted this routine in preparation for the 1938 race.

This topical news item has not been published in the lay press, and is printed here so that those of the Medical Profession who are interested in the nutritional training of athletes, and family practitioners who are consulted by patients indulging in strenuous exercise may be advised of an interesting contribution made by Glaxo Laboratories to one of the major classic sporting events of the year.
The cruising habit seems to be firmly established in this country, but those who Blue enjoy this kind of holiday Funnel are tending to be more Line critical of the amenities offered by cruising ships. By taking Blue Funnel Line Cruises passengers can be assured of travelling in large ocean-going Liners, and can visit China, Japan, Australia, South Africa, Malaya, Ceylon, Egypt, Palestine as well as the Riviera. There are also Special short cruises to Rotterdam returning via the Western Isles to Glasgow for those who can spare only a few days for a holiday.

In March, April, May and October the fare for this voyage, first class only, is £7. 7s. 0d. while in June, July, August and September, it is $£ 8$. 8s. 0d.

When in Rotterdam the ship may be used as a Hotel, so that no expense may be in- 